\title{
Use of Panoramic Dental Radiography for Talent Identification and Development in Youth Soccer: A Pilot Case
}

\author{
Uso de la Radiografía Panorámica para la Identificación de \\ Talentos y el Desarrollo en el Fútbol Juvenil: Caso Piloto
}

\author{
Mariana Merlim Pereira'; Reinaldo Brito e Dias'; Marcelo Rodrigues Lima² \& Neide Pena Coto'
}

PEREIRA, M. M.; DIAS, R. B.; LIMA, M. R. \& COTO, N. P. Use of panoramic dental radiography for talent identification and development in youth soccer: a pilot case. Int. J. Odontostomat., 14(2):141-143, 2020.

ABSTRACT: The aim of the study was to determine the possibility of using panoramic X-ray as an auxiliary tool for the identification of talent in young athletes using the physical body growth indicator. Thirty three radiographs were used of athletes aged 13 to 15 years. Analysis was performed using the Eklof and Ringertz method. Dental age (40\%) came the closest to chronological age. Dental age determined in this study proved to be the most effective radiographic method for the determination of bone maturity for use in the identification of talent through imaging exams. This method was also the simplest and can be performed by the dentist of a sports club without exposing athletes to unnecessary radiation.

KEY WORDS: athletic performance, growth and development, radiography, panoramic, atlhetes.

\section{INTRODUCCIÓN}

The early identification of sports talent has become increasingly important. Physical performance is improved through specific exercises and the systematic determination of skills, potential and physical development (Reilly et al., 2000; Abbott et al., 2005). This evaluation stipulates the training load linked directly to the individual tolerance capacity of each athlete.

Studies have been carried out to establish parameters that can achieve a balance between training load, individual tolerance and the expected result, especially in young athletes. Sports and exercise sciences play an important role in the identification, monitoring and support of athletes in the development of their potential (Williams \& Reilly, 2000; Unnithan et al., 2012).

The prediction of talent in a sport is based on social, physiological, psychological and physical indicators (Williams \& Reilly; Nemet \& Eliakim, 2005). Height, weight, body size, muscle girth, somatotype, body fat and growth are among the physical indicators considered. During growth, bone maturation is reported to be the best method of evaluation (Malina, 2011; Unithan et al., 2012). However, chronological age is not an accurate criterion for this determination. Thus, radiographic exams are used to achieve a precise measure of the bone maturation phase. X-rays of the hand and wrist are commonly employed for this purpose, but involve considerable time, cost and exposure to radiation. The ideal would be to determine bone maturation through radiographs that are habitually required by the medical/dental service of a sports club.

It is common for the dentist of a sports club or athlete to request panoramic radiographs during adolescence, to monitor the development of the occlusion, especially the eruption of third molars. In dentistry, studies on tooth development can be used to determine dental age and, consequently, bone maturation through imaging exams.

To investigate the reliability of the prediction of bone maturation through panoramic radiographs, the

\footnotetext{
${ }^{1}$ Department of Maxillofacial Surgery,Prosthetics and Traumatology,School of Dentistry,University of São Paulo,São Paulo, SP, Brazil.

2 Technical coordinator of the Departament of Grassroots Football, São Paulo, Brazil.
} 
aim of the present study was to compare two methods commonly used for the determination of bone age in young athletes: X-rays of the hand and wrist and panoramic radiography for the determination of dental age.

\section{MATERIAL AND METHOD}

This study involved the use of 33 panoramic radiographs obtained from the medical/dental department of the soccer club studied and 33 carpal radiographs of the same young male athletes aged 13 to 15 years enrolled in a basic soccer program.

Nolla's table of mineralization stages (Nolla, 1960) and a permanent dentition mineralization chronology table were used for the interpretation of the panoramic radiographs. For such, maturation of the lower third molar was analyzed, as the visualization of upper teeth is often hindered by the overlap of maxillary bone structures.

The interpretation of the hand and wrist x-rays involved the use of the two most often employed methods, the "Eklof and Ringertz method" and "Greulich and Pyle method". The Eklof and Ringertz method (Malina) consists of 10 bone parameters: 1width of the distal epiphysis of the radius; 2- capitate length; 3- capitate width; 4- hamate length; 5- hamate width; 6- length of 2nd metacarpal; 7- length of 3rd metacarpal; 8- length of 4th metacarpal; 9- length of 3 rd distal phalange; length of 2 nd proximal phalange; and 10- length of 3rd proximal phalange. The Radiocef Studio 2.0 software program (Radio Memory Ltd. $®$ Belo Horizonte/ Minas Gerais/Brazil) was used for this analysis, which provides a readout with the patient's data and the mean age of each bone analyzed. Bone age based on the method described by Greulich and Pyle was emitted by the radiographic center that performed the carpal $\mathrm{x}$-rays.

This study received approval from the Human Research Ethics Committee of the School of Dentistry of the University of Sao Paulo (Brazil) under process number 00885412.4.0000.0075.

All data were tabulated and submitted to statistical analysis using the Two-Proportion Equality test. A p-value $\leq 0.05$ was considered indicative of statistical significance and $95 \%$ confidence intervals were calculated (Fig. 1).

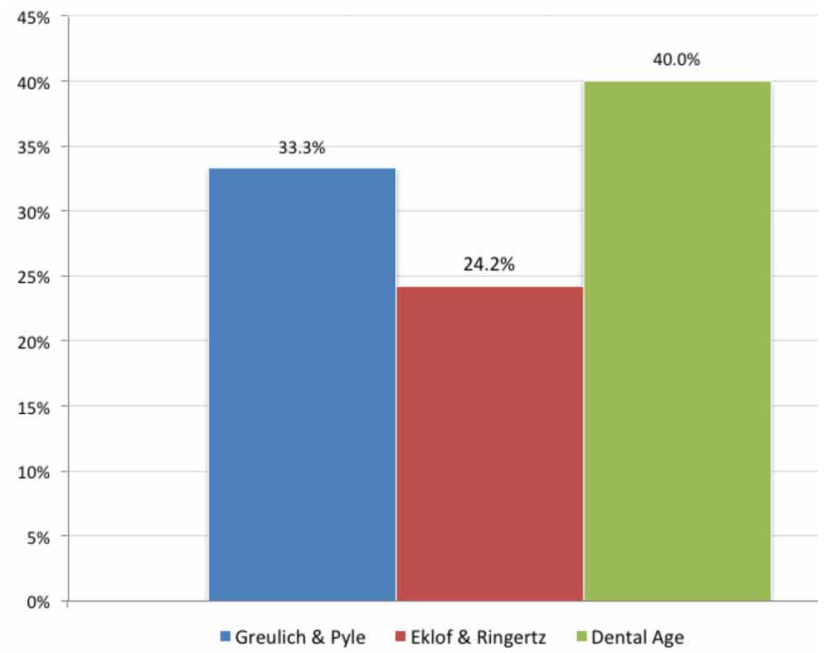

Fig. 1 - Comparison of methods for analysis of hand and wrist x-rays (Greulich \& Pyle and Eklof \& Ringertz) and panoramic radiograph (dental age)

\section{RESULTS AND DISCUSSION}

The aim of the present study was to determine the possibility of using panoramic radiographs employed in dentistry as an auxiliary tool for the detection of talent in young athletes using the physical parameter "body growth".

Bone maturation is commonly determined through the analysis of carpal $\mathrm{x}$-rays. As dentists usually solicit panoramic radiographs for the monitoring of the eruption of third molars in adolescents, the use of this type of imaging for the determination of bone maturation would translate to lesser exposure to radiation on the part of athletes. Indeed, studies report that the evaluation of tooth mineralization is a more reliable and efficient method than the mere analysis of the presence of non-erupted teeth and state that the study of a specific tooth is more viable and precise than studying a maturation scale that includes the majority of teeth (Nolla; Demirjian et al., 1973; Demirjian et al., 1985).

Despite the lack of statistically significant differences among the different methods analyzed, the present findings demonstrate that the use of panoramic radiographs for the determination of dental age was the most efficient for the determination of bone maturation in adolescents. Thus, the analysis of a single tooth in dental $x$-rays (panoramic or periapical radiographs) could be considered the method of choice in the establishment of training programs based on 
factors used for the detection of talent in young athletes. However, this method depends on the age group of the athlete.

In the comparison of the analysis methods involving $\mathrm{x}$-rays of the hand and wrist, the determination of bone maturation based on panoramic radiographs came closest to chronological age. This finding is in agreement with forensic dentistry, which enables the estimation of age through the determination of dental development.

In conclusion, dental age determined from the study of the development of the lower third molar proved to be the most effective radiographic method for the determination of bone maturity for use in the identification of talent through imaging exams. This method was also the simplest and can be performed by the dentist of a sports club without exposing athletes to unnecessary radiation.

PEREIRA, M. M.; DIAS, R. B.; LIMA, M. R. \& COTO, N. P. Uso de la radiografía panorámica para la identificación de talentos y el desarrollo en el fútbol juvenil: Caso piloto. Int. J. Odontostomat., 14(2):141-143, 2020.

RESUMEN: El objetivo del estudio consistió en determinar la posibilidad de usar radiografía panorámica como herramienta auxiliar para la identificación de talentos en los atletas usando el indicador de crecimiento del cuerpo físico. Fueron utilizadas 33 radiografías de atletas, de entre 13 a 15 años. Se realizó un análisis de la aplicación utilizando el método de Eklof y Ringertz. Se encontró que la edad dentaria (40 \%) se aproximó a la edad cronológica. La edad dental utilizada en este estudio demostró ser el método radiográfico más efectivo para la determinación de la madurez ósea para su uso en la identificación del talento a través de exámenes de imágenes. Este método también fue el más simple y puede ser realizado por el dentista de un club deportivo sin exponer a los atletas a radiaciones innecesarias.

PALABRAS CLAVE: desempeño atlético, crecimiento y desarrollo, radiografía panorámica, atletas.

\section{REFERENCES}

Abbott, A.; Button, C.; Pepping, G. J. \& Collins, D. Unnatural selection: talent identification and development in sport. Nonlinear Dynamics Psychol. Life Sci., 9(1):61-88, 2005.

Demirjian, A.; Buschang, P. H.; Tanguay, R. \& Patterson, D. K. Interrelationships among measures of somatic, skeletal, dental, and sexual maturity. Am. J. Orthod., 88(5):433-8, 1985.

Demirjian, A.; Goldstein, H. \& Tanner, J. M. A new system of dental age assessment. Hum. Biol., 45(2):211-27, 1973.
Malina, R. M. Skeletal age and age verification in youth sport. Sports Med., 41(11):925-47, 2011.

Nemet, D. \& Eliakim, A. Growth hormone-insulin-like growth factor1 and inflammatory response to a single exercise bout in children and adolescents. Med. Sport Sci., 55:141-55, 2005.

Nolla, C. M. The development of the permanent teeth. J. Dent. Child., 27:254-66, 1960.

Reilly, T.; Williams, A. M.; Nevill, A. \& Franks, A. A multidisciplinary approach to talent identification in soccer. J. Sports Sci., 18(9):695-702, 2000.

Unnithan, V.; White, J.; Georgiou, A.; Iga, J. \& Drust, B. Talent identification in youth soccer. J. Sports Sci., 30(15):1719-26, 2012.

Williams, A. M. \& Reilly, T. Talent identification and development in soccer. J. Sports Sci., 18(9):657-67, 2000.

Corresponding author:

Neide Pena Coto

Department of Maxillofacial Surgery

Prosthetics and Traumatology

School of Dentistry, University of São Paulo

Avenida Lineu Prestes, 2227

Cidade Universitária - São Paulo

BRAZIL

Email: npcoto@usp.br

Received: 17-05-2019

Accepted: 17-10-2019 